\title{
Perancangan Design Tata Letak Fasilitas SPBG Dengan Menggunakan Metode Konvensional Berbasis 5R (Ringkas, Rapi, Resik, Rawat, Rajin)
}

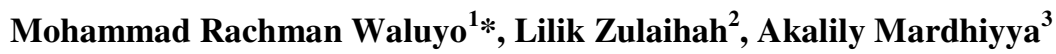 \\ ${ }^{1,2}$ Jurusan Teknik Industri, Universitas Pembangunan Nasional "Veteran" Jakarta \\ ${ }^{3}$ Jurusan Teknik Elektro, Universitas Pembangunan Nasional "Veteran" Jakarta \\ Jl. RS. Fatmawati No. 1, Pondok Labu , Jakarta Selatan \\ *E-mail: aanvicenzo@gmail.com
}

\begin{abstract}
Abstrak
Perancangan fasilitas merupakan salah satu faktor yang sangat berpengaruh pada kinerja suatu perusahaan. Hal ini disebabkan oleh tata letak fasilitas yang kurang baik akan menyebabkan pola aliran bahan yang kurang baik dan perpindahan bahan, produk, informasi, peralatan dan tenaga kerja menjadi relatif tinggi yang menyebabkan keterlambatan penyelesaian dan menambah biaya operasional. Hal ini dibuat untuk menciptakan kelancaran aliran bahan, sehingga nanti dapat diperoleh aliran bahan yang efisien dan kondisi kerja yang teratur.Permasalahan layoutSPBG merupakan permasalahan yang tidak dapat dihindari oleh pemilik SPBG dalam operasinya. Jauhnya jarak perpindahan material dari departemen kerja yang satu dengan departemen kerja lainnya akan mempengaruhi totalitas perusahaan dalam meningkatkan produktivitas dan profitabilitas. Penelitian ini bertujuan untuk mengetahui total perpindahan minimum sehingga nantinya diperoleh final layout yang terbaik dan dapat meminimalkan biaya. Penelitian ini menerapkan metode 5R pada penyusunan tata letak fasilitas SPBG di Pondok Labu untuk memperoleh tata letak yang lebih rapi, yaitu Ringkas,Rapi, Resik, Rawat dan Rajin.
\end{abstract}

Kata Kunci : Perancangan Layout SPBG, 5R, Metode Konvensional, Perancangan Fasilitas

\section{Pendahuluan}

Perancangan fasilitas SPBG merupakan salah satu faktor yang sangat berpengaruh pada kinerja suatu perusahaan. Hal ini disebabkan oleh tata letak fasilitas yang kurang baik akan menyebabkan pola aliran bahan yang kurang baik dan perpindahan bahan, produk, informasi, peralatan dan tenaga kerja menjadi relatif tinggidan menambah biaya produksi. Tata letak dapat didefinisikan sebagai tata cara pengaturan fasilitas-fasilitas pabrik guna menunjang kelancaran proses produksi [1]. Pengaturan tersebut akan memanfaatkan luas area untuk menempatkan mesin Mobile Refuiling Unitdan fasilitas penunjang produksi lainnya, kelancaran gerak perpindahan material baik bersifat temporer maupun permanen, personal pekerja dan lain sebagainya. Dalam tata letak pabrik terdapat 2 (dua) hal yang harus diperhatikan yaitu pengaturan mesin dan pengaturan untuk segala aktifitas di SPBG itu sendiri. Dengan adanya perencanaan tata letak yang baik, maka gerakan bolak-balik, jarak momen perpindahan material dan biayadapat diminimumkan.Masalah penelitian ini terletak pada belum ada gambaran baku tentang tata letak fasiltas SPBG yang baik seperti apa sehingga membutuhkan perbaikan tata letak fasilitas berbasiskan metode konvensional berbasis 5R(ringkas, rapi, resik, rawat, rajin). Memberi solusi dan alternatif terbaru terhadap permasalahan di perusahaan yang terkait dengan tata letak pabrik yang efektif dan efisien, Sebagai pengaplikasian dan dedikasi terhadap perkembangan ilmu pengetahuan, sains dan teknologi, dan Sebagai bagian pengabdian terhadap perkembangan kehidupan masyarakat khususnya disiplin ilmu keteknikan. 


\section{Perencanaan dan Pengaturan Tata Letak Pabrik}

Tata letak fasilitas dapat didefinisikan sebagai tata cara pengaturan fasilitas-fasilitas guna menunjang kelancaran proses yang terjadi. Pengaturan tersebut berguna untuk luas area penempatan MRU(Mobile Refueling Unit) dan fasilitas penunjang lainnya, kelancaran gerakan perpindahan material, jalur mobil MRU masuk untuk berhenti menunggu antria ke line pengisian, dan pekerja dan sebagainya. Tata letak ada dua hal yang diatur letaknya yaitu pengaturan mesin dan pengaturan departemen yang ada dari pabrik.

Pada umumnya tata letak yang terencana dengan baik akan ikut menentukan efisiensi dan dalam beberapa hal akan juga menjaga kelangsungan hidup ataupun kesuksesan kerja suatu industri. Peralatan dan suatu desain produk yang bagus akan tidak ada artinya akibat perencanaan tata letak yang sembarangan saja karena aktivitas suatu industri secara normalnya harus berlangsung lama dengan tata letak yang tidak selalu berubah-ubah.

Tujuan utama didalam desain tata letak pada dasarnya adalah untuk meminimalkan total biaya yang antara lain menyangkut elemen biaya seperti biaya untuk kontruksi dan instalasi baik untuk bangunan, mesin, maupun fasilitas lainnya. Selain itu biaya pemindahan bahan, biaya produksi, perbaikan, keamanan, biaya penyimpanan produk setengah jadi dan pengaturan tata letak yang optimal akan dapat pula memberikan kemudahan di dalam proses supervisi serta menghadapi rencana perluasan pabrik kelak dikemudian hari [3].

\section{Kaizen Metode 5R}

Metode 5R merupakan tahap untuk mengatur kondisi tempat kerja yang berdampak terhadap efektifitas kerja, efisiensi, produktifitas dan keselamatan kerja.Salahsatu cara menciptakan suasana kerja yang nyaman adalah perusahaanmenerapkan sikap kerja 5R[2]. Lingkungan kerja yang sebelumnya kurang nyaman bagi pekerja dapat diperbaiki.Prinsip kerja 5R ini merupakan satu kesatuan dengan Kaizen (perubahan yang lebih baik) dimana pada prinsip kaizen terdapat dua hal penting yaitu kaizen $5 \mathrm{R}$ (perapihan lingkungan dan tempat kerja) dan kaizen proses. Jika kaizen 5R memulai dari hal-hal yang bersifat fisik seperti pengaturan persediaan, penempatan bahan baku, perapihan tempat kerja dan menempatkan segala sesuatu pada tempatnya, maka pada kaizen proses yang dilaksanakan adalah efisiensi.

\section{Metode Penelitian}

Metode yang digunakan metode rancangan konvensional dengan penerapan metode 5R, yaitu Ringkas (pemilihan) diterapkan pada ruang mekanik yaitu meletakkan peralatan pada tempatnya dan minyisihkan yang tidak perlu sehingga tidak membutuhkan waktu yang lama dalam menyelesaikan tugasnya, Rapi (penataan) yaitu barang-barang yang telah melewati proses Rapidilanjutkan dengan proses penataan peralatan yang telah dipilih tersebut, Resik (pembersihan) dilakukan pembersihan pada lantai produksi dan peralatan yang diperlukan pada proses produksi seperti mesin dan lain-lain, Rawat (pemantapan) disini dilakukan pemantapan terhadap metode 5R yang telah diterapkan, supaya penerapan metode $5 \mathrm{R}$ yang telah dilakukan tetap berlangsung terus menerus dan juga dilakukan pembuatan garis batas area kerja yang bertujuan agar penyusunan peralatan kerja lebih tertata dengan baik dan Rajin (pembiasaan) pada bagian ini lebih difokuskan bagaimana untuk membiasakan diri terhadap penerapan metode $5 \mathrm{R}$ ini.

\section{Hasil Dan Pembahasan}

\section{Pemilihan Lokasi}

Faktor-faktor utama yang digunakan dalam menentukan lokasi adalah letak konsumen potensial, sasaran yang akan dijadikan tempat produk dijual, letak bahan baku utama, sumber tenaga kerja, sumber daya seperti air, kondisi udara, tenaga listrik dan sebagainya. Untuk lokasi SPBG MRU rencanya disekitarJalan Pondok Labu, Jakarta Selatan karena jalanan yang sering dilewati angkutan umum. Berikut kriteria-kriteria yang dipenuhi oleh lokasi dikawasan Pondok Labu: 1) Berada di 
daerahbukan residensial, hal ini berkaitan dengan keamanan dan keselamatan akan kekhawatiran gas yang dapat meledak. 2) Dilalui banyak kendaraan dan dekat dengan jalur angkutan umum. 4) Lokasi tidak menimbulkan kemacetan jika terjadi antrian pengisian 5) Lokasi strategis dan akses ke lokasi mudah. 6) Luas MRU membutuhkan luas 600-800.

\section{1) Activity Relationship Chart (ARC)}

Tahapan awal ARC adalah menentukan departemen dan fasilitas yang harus dimiliki SPBG, yaitu:

1. Line pengisian MRU

2. Kamar mandi

3. Line Standby mobil MRU

4. Kantor

5. Parkir

6. Gudang mekanik / genset

7. Ruang istirahat pegawai pengisian SPBG

8. Mushalla

9. Tempat Makan/ Rest area 
Jurnal Teknologi dan Manajemen Industri, Vol. 5 No. 2, Agustus 2019

Pascasarjana Institut Teknologi Nasional Malang

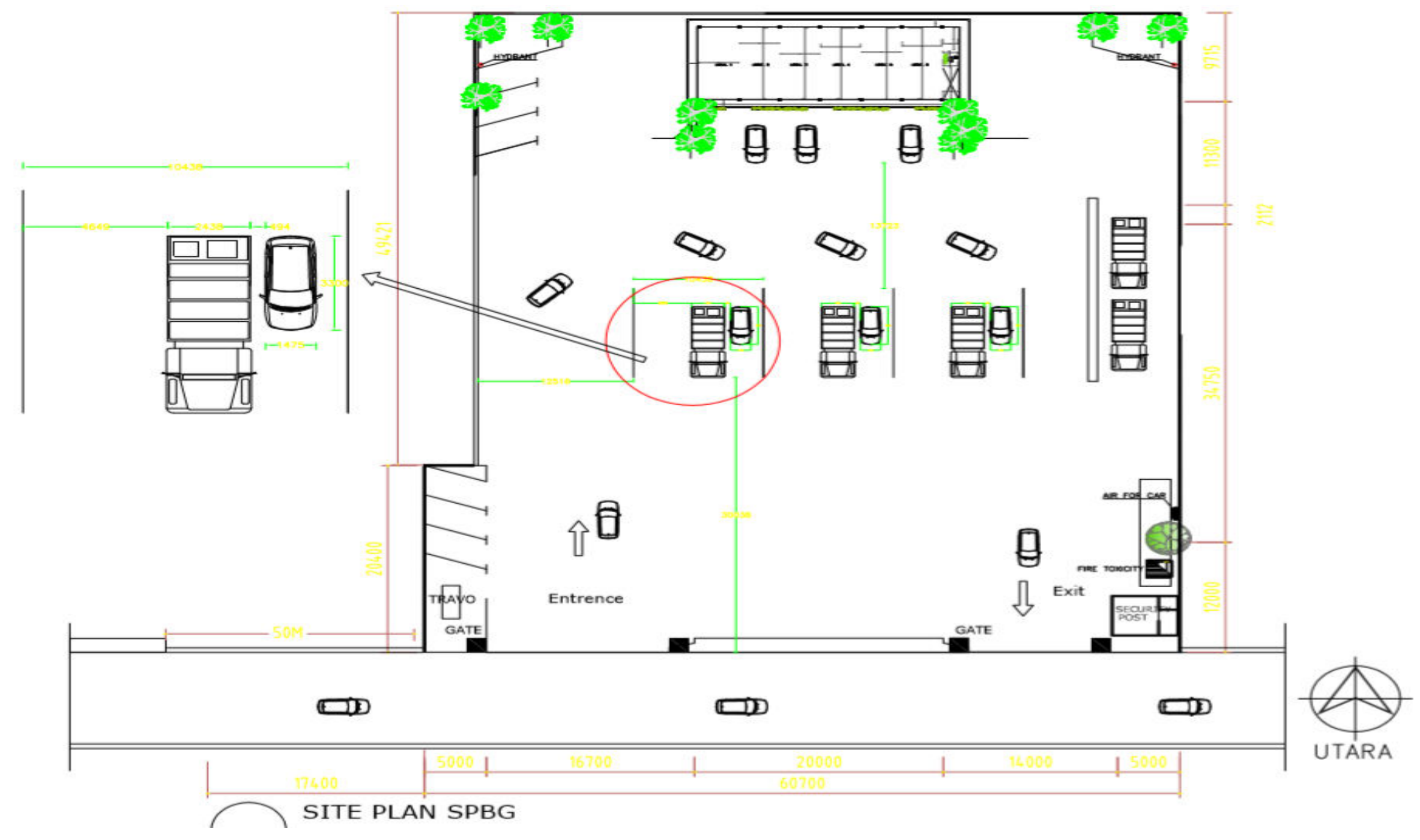

Gambar 1.Layout Pendirian SPBG 
Adapun penerapan metode 5Rakan diterapkan pada pendirian SPBG sebagai berikut:

1. Ringkas

Metode Ringkas diterapkan pada letak tata letak fasilitas SPBG karena pada departemen ini terlihat jelas banyaknya peralatan mekanik.Peralatan yang tidak diperlukan pada gudang mekanik ini membuat lantai menjadi penuh sehingga tempatuntuk pekerja melakukan perbaikan mesin / alat - alat yang rusak.Melihat keadaan tersebut maka diterapkanlah ringkasyaitu dengan melakukan pemilahan terhadap peralatan yang tidak diperlukan agar dapat disimpan agar terpisah dengan peralatan yang dibutuhkan.Ringkasakan diterapkan untuk memperoleh hasil yaitu keadaan lantai agar terlihat lebih memiliki ruangsehingga pekerja lebih leluasa untuk melakukan pekerjaannya.

2. Rapi

Metode Rapimerupakan pemilahan yang telah dilakukan akan dilanjutkan dengan proses penataan semua peralatan yang telah dipisah. Dalam hal ini peralatan yang ada pada gudang mekanik ditata rapi yaitu ditempatkan didalam rak peralatan mekanik yang dibuat dari papan dan ditempelin nama-nama barangsehingga pekerja lebih mudah mengambil dan menggunakannya, tidak membutuhkan waktu yang lama saat mencari peralatan yang diperlukan karena sudah ada namanya masing-masing dan dilakukan pemisahan area atar ruangan.

3. Resik

Pada tahap ini hal yang dilakukan adalah proses pembersihan. Adapun pembersihan yang dilakukan adalah pembersihan debu dan sampah dilantai produksi dan peralatan yang digunakan untuk proses produksi, peralatan yang di bersihkan. Pembersihan area SPBG ini bertujuan demi keamanan dan kenyaman pekerja pada saat melakukan pekerjaanya.Sedangkan untuk pembersihan peralatan kerja dilakukan dengan tujuan perawatan terhadap peralatan tersebut.

4. Rawat

Pada tahap ini dilakukan upaya secara continuous improvement.Selain itu juga dilakukan pembuatan linebatas area kerja yang bertujuan agar penyusunan kinerja \& peralatan kerja lebih tertata dengan baik.

5. Rajin

Tahap ini merupakan bagian terakhir dari metode 5R. Pada bagian ini lebih memfokuskan bagaimana cara untuk membiasakan diri terhadap penerapan 5R, untuk itu diperlukan kesadaran dari para pekerja untuk memiliki pola kerja yang sesuai demi kenyamanan dan keamaan dalam bekerja. Mengingat sifat manusia yang berbeda-beda, maka perlu seseorang yang bisa mengontrolnyauntuk peduli dan mampu mengontrol pekerja agar selalu menjaga lingkungan kerja berdasarkan metode $5 \mathrm{R}$ yang telah diterapkan.

\section{Kesimpulan}

Adapun kesimpulan dari penelitian yang sudah dilakukan adalah Rancangan tata letak fasilitas pendirian SPBG.Penelitian ini menerapkan metode 5R pada penyusunan tata letak fasilitas pendirian SPBG untuk memperoleh tata letak yang lebih rapi dan terorganisir.

\section{Daftar Pustaka}

[1] Hadiguna, R. A dan Setiawan, H. (2008).Tata Letak Pabrik.Andi.Yogyakarta.

[2] Jahja, Kristanto. 2009. Seri Budaya Unggulan 5R (Ringkas, Rapi, Resik, Rawat, Rajin). Jakarta: Penerbit PMM

[3] Wignjosoebroto, Sritomo., 2009, "Tata Letak Pabrik dan Pemindahan Bahan", Guna Widya, Surabaya 